\title{
A Dry Ashing Method for the Determination of Blood Lead using Cathode Ray Polarography
}

\author{
Comparison with a Wet Ashing Technique
}

\author{
A. A. CERNIK \\ From the Medical Branch, H.M. Factory Inspectorate, Ministry of Labour, London
}

A dry ashing method is described for the determination of lead in whole blood. Within the range of 16-200 $\mu$ g. lead per $100 \mathrm{ml}$. blood recoveries were 82 to $100 \%$. The method agreed with a standard wet method and is more convenient. Possible sources of error and the uses of the ashing aid are discussed.

Great care is needed in preparing specimens of blood for the estimation of trace amounts of lead. With 3-5 ml. of blood less than $2 \mu \mathrm{g}$. of lead may be present. Such an amount can be estimated accurately with modern instruments; but it is essential to avoid both contamination and losses.

The organic matter in blood is usually removed by wet ashing with hot mineral acids. This is tedious as it requires close attention at critical stages, and the reagent blanks may be comparable with the lead in blood, resulting in low precision.

Organic matter can be removed by dry ashing in which the organic matter is removed by atmospheric oxidation. When properly performed in a thermostatic muffle furnace, it needs little attention as the ashing can be arranged overnight, the residue is completely soluble in the supporting electrolytes, and recoveries are complete because no insoluble salts are present. Ashing aids can be obtained which contain very little lead, so the reagent blanks are low. Temperature control is important. As temperatures approach $550^{\circ} \mathrm{C}$. recoveries fall because lead is volatilized and is retained on the silica crucible (Gorsuch, 1959). Temperature gradients can exist in thermostatically controlled ovens, especially in the back six inches (Hamilton, $\mathrm{Minski}_{2}$ and Cleary, 1967). Consequently, it is preferable to ash at temperatures well below $550^{\circ} \mathrm{C}$., and to find a temperature at which fluctuations are not critical.

Described here is a convenient dry ashing procedure which compares well for precision with a standard wet ashing procedure.

Received for publication October 5, 1966.

\section{Materials and Methods}

Blood Specimens Venous blood (10.0 ml.) was collected with a disposable plastic syringe and emptied into a plastic bottle containing I0-20 mg. disodium ethylenediamine tetra-acetic acid as an anticoagulant.

Polarograph This was the Davis Differential Cathode-Ray Polarograph Ar66o (Southern Analytical, Camberley, Surrey).

\section{Dry Ashing Procedure}

Reagents Magnesium oxide, MgO, Analar; hydrochloric acid, $\mathrm{HCl}$, Analar; lead acetate, $\mathrm{Pb}\left(\mathrm{CH}_{3} \cdot \mathrm{CO}_{2}\right)_{2} \cdot 3 \mathrm{H}_{2} \mathrm{O}$, Analar ( $\mathrm{Img}$. $\mathrm{Pb} / \mathrm{ml}$. in $1 \%$ acetic acid, $\mathrm{v} / \mathrm{v}$ ); peptone, bacteriological grade (Griffin and George, Ltd.); water, glass distilled and deionized to better than $2 \mathrm{megohms} / \mathrm{cm}$. (Elgastat).

Method Into a silica crucible, $57 \times 37 \mathrm{~mm}$., place $250 \mathrm{mg}$. $\mathrm{MgO}$ and $5.0 \mathrm{ml}$. well mixed whole blood. Thoroughly stir the $\mathrm{MgO}$ into the blood with a fine glass rod. Wash the blood off the rod with distilled water. Dry the specimen at $110^{\circ} \mathrm{C}$. for four to six hours. When it is dry, set the temperature control to $460^{\circ} \mathrm{C}$. so that the temperature increases from $110^{\circ} \mathrm{C}$. to $460^{\circ} \mathrm{C}$. in not less than three hours. Ash for 16 hours at $460^{\circ} \mathrm{C}$. Remove the crucible carefully, as any draught causes the light residue to lift instantly, and place in a fume cupboard to cool to $40-50^{\circ} \mathrm{C}$. Add $2.0 \mathrm{ml}$. concentrated hydrochloric acid, washing the walls of the crucible with the acid. Care is needed as the reaction is vigorous. Leave for at least to min., but swirl the acid gently around the walls of the crucible every $3 \mathrm{~min}$. or so during this time. Any solid lumps noticed at first will gradually disintegrate in the acid. If necessary, final solution can be effected with a glass rod. Deionized water $(8 \mathrm{ml}$.) is added and mixed, and $4.0 \mathrm{ml}$. of the solution is placed in a polarograph cell, degassed with $\mathrm{O}_{2}$-free $\mathrm{N}_{2}$ for I-2 min. and $\mathrm{I}-2 \mathrm{mg}$. of peptone are added. Peak wave 
potential for lead under these conditions is about 0.49 volt.

The polarograph was standardized for each estimation by adding $0.01 \mathrm{ml}$. of the standard lead solution (I $\mathrm{mg} . / \mathrm{ml}$.) and re-estimating.

Wet Ashing Procedure A modification of the M.R.C. method for wet ashing of blood (Analytical Methods Committee, 1959) was used.

Reagents Nitric acid (Analar, s.g. I·42); perchloric acid (Analar, s.g. I·70); hydrochloric acid (Analar, s.g. $\mathrm{I} \cdot \mathrm{I} 8$ ); hydrogen peroxide (Analar, 30\% w/v); glass distilled water, deionized.

Glassware $25 \times 150 \mathrm{~mm}$. rimless Pyrex test tubes. Wash in 50\% nitric acid and keep for lead work only.

Specially designed heating blocks obtained from Southern Analytical, Camberley, Surrey, were copied and made from aluminium alloy (Luckham, Ltd.). The blocks were in two parts, a top half and a bottom half, drilled to take the test tubes, leaving $I \mathrm{~cm}$. exposed at the top when the blocks were together (Fig. I).

Method Well mixed whole blood ( $5 \mathrm{ml}$.) is pipetted into the tube, followed by $5.0 \mathrm{ml}$. nitric acid. Gently heat on an electric hotplate using the lower block so that the acid refluxes for at least the first hour. When the acid is reduced to about $\mathrm{I} \cdot 0 \mathrm{ml}$. take the tube out of the block and add $5.0 \mathrm{ml}$. of a $\mathrm{I} / \mathrm{r}, \mathrm{v} / \mathrm{v}$ mixture of nitric and perchloric acids. Replace the tube in the bottom block and gently reduce the volume by heating until fumes appear. Then place the upper block over the tube and raise the temperature of the hotplate to maximum to drive off the last traces of acid. To the tube add carefully, while hot but dry, about $\mathrm{I} \cdot 0 \mathrm{ml}$. hydrogen peroxide and resume heating until completely dry. Remove the tube, cool a little and, whilst still hot, pipette $9.0 \mathrm{ml}$. water and $\mathrm{r} \cdot 0 \mathrm{ml}$. concentrated hydrochloric acid to dissolve the residue. A reagent blank is prepared as follows: Io $\mathrm{ml}$. water is placed in a plastic blood bottle and shaken; $5.0 \mathrm{ml}$. of this is then treated in exactly the same way as blood.

The method differs from the standard method in substituting hydrogen peroxide for sulphuric acid. The latter gives complex base lines on the polarograph.
Polarography At the levels of lead found when working with ashed samples of normal blood, supporting electrolytes produce somewhat distorted waves. Such samples require the polarograph to be used at near maximum sensitivity and to have sloping base lines. According to Tyler (1964), the purest base electrolyte will not give horizontal base lines on the cathode-ray polarograph. The mercury solution interface of the dropping mercury-electrode behaves as a condenser whose capacity varies in a complex manner with the applied voltage. The differential capacity hump at the voltage of the electro-capillary maximum can be confused with the oxygen response. Ascorbic acid has been used to alter the shape of the differential capacity curve, and thereby to give an improved shape to the lead wave. A crystal of solid peptone was found to be even more effective in producing a clear trace when added to the $\mathrm{HCl}$ solution of lead in the polarograph cell.

The lead wave when no peptone is used shows (Fig. 2) a trailing slope which has affected its height which should be directly proportional to the concentration of lead. Figure 3 shows the same lead wave with peptone added. Slope correction is still needed. When this is made the same lead wave shows a true linear relationship to lead concentration (Fig. 4).

Small adjustments to the starting potential are sometimes necessary when the trailing slope of the wave dips below the base line. This is used in conjunction with slope compensation. An ideal polarographic trace should sweep off about one-third of the way down from the peak.

Very small volumes (0.01 ml.) added from an Agla micro pipette, delivering strong standard lead solutions, do not, for practical considerations, affect the original volume. With these conditions lead, in a concentration of $0.1 \mu \mathrm{g} . / \mathrm{ml}$. frequently gave a measurable wave 6.0 $\mathrm{cm}$. high, at maximum sensitivity.

\section{Results}

Ashing Aid Blood can be ashed without an aid in a silica crucible but, when the lead content is small, using one reduces the risks of volatilization
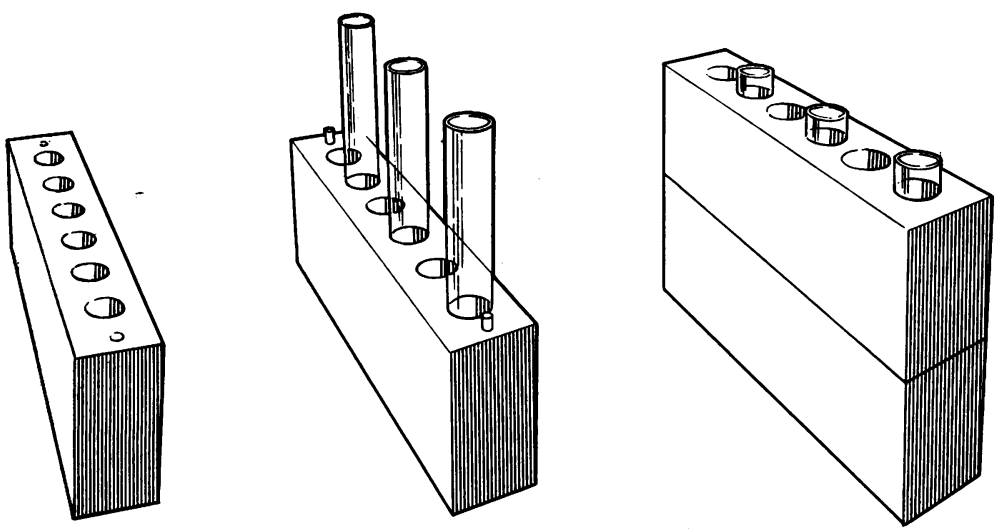

Fig r. Block for wet-ashing. 


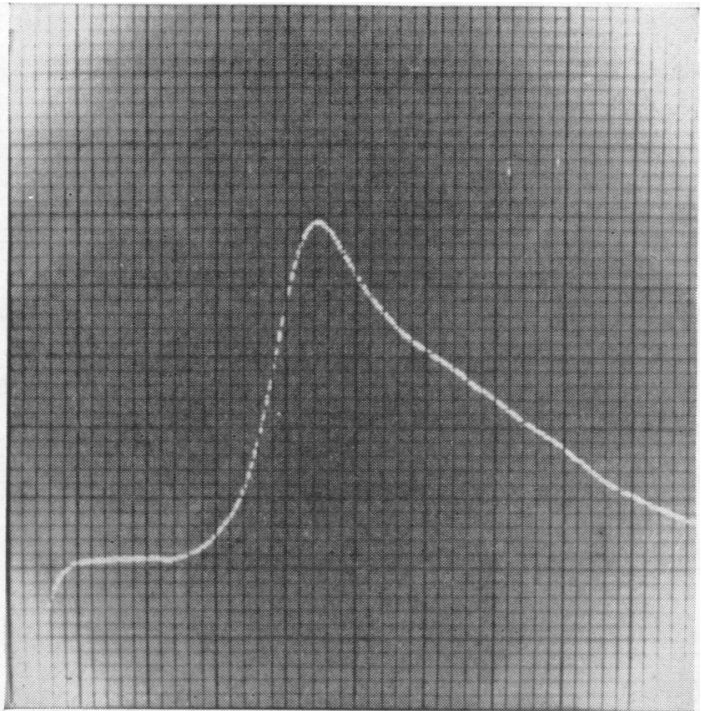

FIG. 2 Polarographic wave produced by lead, with no peptone or slope correction

and retention on the crucible. Boric acid, aluminium oxide, and magnesium nitrate have been used successfully (Gorsuch, 1959). Preliminary observations showed that $\mathrm{MgO}$ was satisfactory. Amounts over $250 \mathrm{mg}$. were inconvenient as they gave ionic concentrations too great to use in the polarograph without dilution and loss of sensitivity; and Io mg. was not enough to avoid retention of lead on the

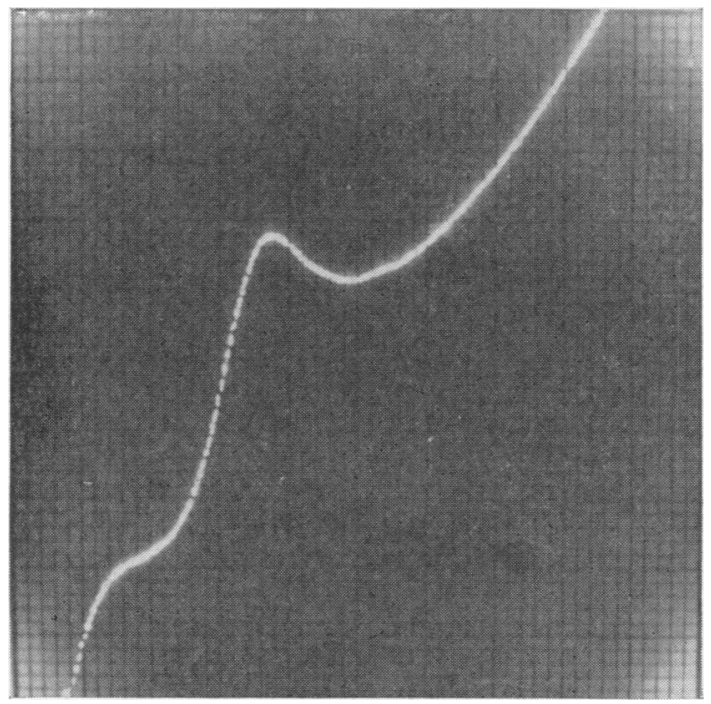

FIG. 3. Polarographic wave produced by lead, with peptone.
TABLE I

Recovery of Lead from Different Amounts of MgO WITH $5 \mu$ G. LeAD AdDED AFTER Heating AT $460^{\circ} \mathrm{C}$. FOR I6 HRS

\begin{tabular}{c|c}
\hline $\mathrm{MgO}(\mathrm{mg})$. & $\%$ Lead Recovered \\
\hline 100 & $\begin{array}{c}92 \cdot 5,97 \cdot 5,93 \cdot 5 \\
105,103,100 \\
250\end{array}$ \\
\hline
\end{tabular}

crucible. Hence $5 \mu \mathrm{g}$. of lead in $5 \mathrm{ml}$. of water were added to $100 \mathrm{mg}$. or $250 \mathrm{MgO}$, and ashed. The results (Table I) show that $250 \mathrm{mg}$. $\mathrm{MgO}$ gave better recoveries. The reagent blanks were equivalent to about $2.5 \mu \mathrm{g}$. $\mathrm{Pb} / \mathrm{IOO} \mathrm{ml}$. of blood. These are so small they can be ignored.

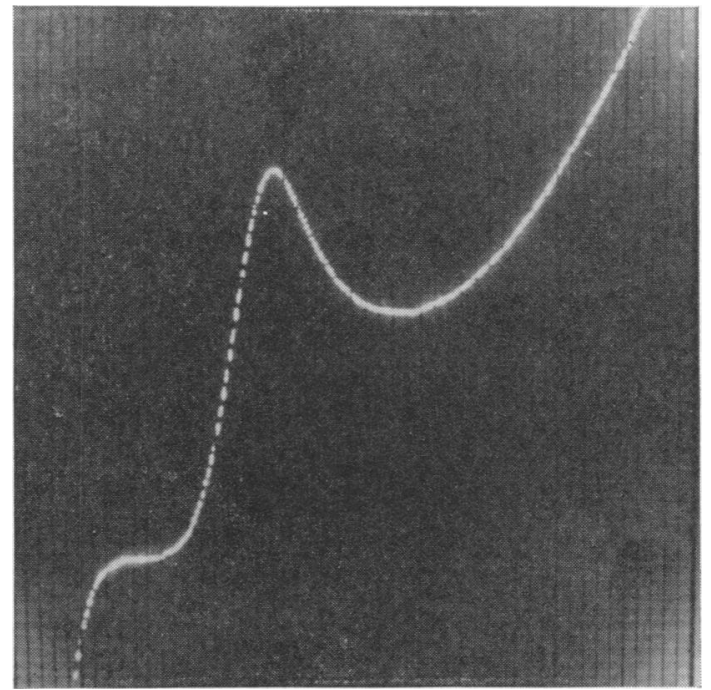

Fig. 4. Polarographic wave produced by lead, with peptone and slope correction.

Hydrochloric Acid as a Solute The ash will only dissolve completely in a strong mineral acid, and hydrochloric acid was chosen because it gave the least complicated base lines during polarography. The volume chosen, $2.0 \mathrm{ml}$, was enough to dissolve all the lead, as shown by the recoveries in Table II.

Ashing Conditions Preliminary experiments showed that $250 \mathrm{mg}$. MgO was satisfactory for $3-5 \mathrm{ml}$. of blood but not enough for volumes outside this range.

Ashing was incomplete after $8 \mathrm{hrs}$ at $460^{\circ} \mathrm{C}$. but was complete by $16 \mathrm{hrs}$, as shown by inspection of the ash and by recovery tests (Table III). 


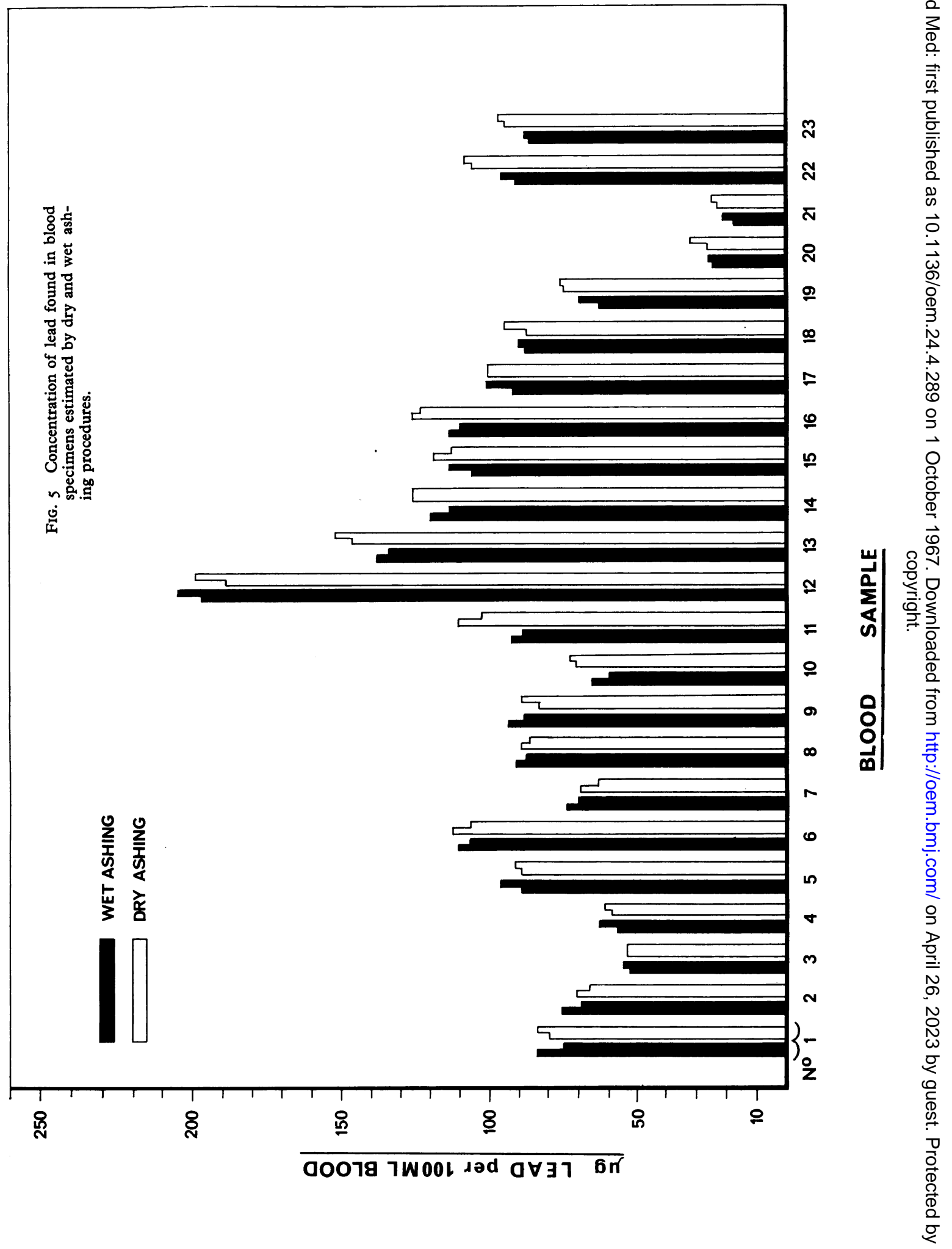


TABLE II

ReCOVERY OF Lead From Blood Residues Dissolved IN 2.0 ML. HYDROCHLORIC ACID AFTER DRY ASHING AT $460^{\circ} \mathrm{C}$. FOR I $6 \mathrm{HRS}$

\begin{tabular}{|c|c|c|c|}
\hline Sample & $\begin{array}{l}\text { Vol. of } \\
\text { Blood Used } \\
\quad(\mathrm{ml} .)\end{array}$ & 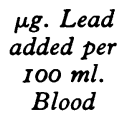 & 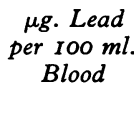 \\
\hline$\stackrel{\text { A }}{\text { Lead worker }}$ & $\begin{array}{l}5 \cdot 2 \\
5 \cdot 2 \\
5 \cdot 2 \\
5 \cdot 2 \\
5 \cdot 6 \\
5 \cdot 5\end{array}$ & $\begin{array}{l}\text { Nil } \\
\text { Nil } \\
\text { Nil } \\
\text { Nil } \\
\text { Nil } \\
\text { Nil }\end{array}$ & $\begin{array}{l}67 \\
66 \\
74 \\
73 \\
69 \\
67\end{array}$ \\
\hline $\begin{array}{c}\text { B } \\
\text { Laboratory worker }\end{array}$ & $\begin{array}{l}5 \cdot 5 \\
5 \cdot 0 \\
5 \cdot 0 \\
5 \cdot 0 \\
5 \cdot 0\end{array}$ & $\begin{array}{r}\mathrm{Nil} \\
50 \\
60 \\
70 \\
100\end{array}$ & $\begin{array}{r}16 \\
61 \\
72 \\
99 \\
116\end{array}$ \\
\hline
\end{tabular}

TABLE III

Recovery of Lead From Whole Blood Dry Ashed at $460^{\circ} \mathrm{C}$. FOR VARYING TIMES EMPLNYING $250 \mathrm{MG}$. MGO AND $2 \cdot 0 \mathrm{ML}$. HCL AS THE SOLUTE

\begin{tabular}{c|c|c}
\hline Time of Heating & $\begin{array}{c}\text { Lead Content } \\
(\mu \mathrm{g} . / \mathrm{IOO} \mathrm{ml} . \text { blood })\end{array}$ & $\begin{array}{c}\text { roo } \mu \mathrm{g} . \text { Lead } \\
\text { added per } \\
\text { Ioo ml. Blood }\end{array}$ \\
\hline I6 hours & $16 \cdot 0$ & \\
Sample A & $16 \cdot 7$ & \\
\hline 20 hours & $18 \cdot 6$ & \\
Sample B & $15 \cdot 6$ & \\
\hline I6 hours & $20 \cdot 0$ & 144 \\
Sample C & 53 & 148 \\
\hline
\end{tabular}

Comparison of Dry and Wet Ashing Both methods were applied in duplicate to the blood of 23 workers exposed to lead and are shown in Figure 5. The reagent blank of $5 \mu \mathrm{g}$./ $100 \mathrm{ml}$. blood has been subtracted from all estimates made by the wet-ashing method. This blank is an unusually low one.

\section{Discussion}

Piper (1944) drew attention to the dangers of crucible retention, and Gorsuch (1959), in his comprehensive paper, showed that losses from the crucible in dry ashing procedures depended mainly on the temperature of oxidation; the crucible material, whether silica, platinum or porcelain; the number of assays the crucible had been used for; and the ashing aid.

The temperature used, $460^{\circ} \mathrm{C}$., is well below red heat, the critical temperature for lead (Fairhall, 1922), and advocates of wet ashing would accept that serious loss by volatilization would not occur at this temperature. The time, $16 \mathrm{hrs}$, may seem long, but not if considered with the convenience of overnight ashing. The time taken to dry the blood is important. This procedure should not be hastened as a much more finely divided residue is obtained with the suggested time.

$\mathrm{MgO}$ was shown to be an excellent ashing aid, but there is an optimum amount to ensure uniform contact with the lead during oxidation.

The dissolution of the ash is of the greatest importance. The clarity of the digest is no indication that the lead is completely in solution. Ferrett, Milner, and Smales (1954) used I $\cdot 0 \mathrm{ml}$. concentrated $\mathrm{HCl}$ plus $\mathrm{I} \cdot 0 \mathrm{ml}$. water with warming to dissolve the ash. The use of this mixture by Gorsuch (1959) might explain some of the retention losses that he found. He also found retention losses of 56 and $62 \%$ when $10 \mathrm{mg}$. $\mathrm{NaCl}$ was present in the crucible.

The chloride content of whole blood (450-5 IO mg. per $100 \mathrm{ml}$. blood) is such that a $5.0 \mathrm{ml}$. specimen contains $20-25 \mathrm{mg}$. $\mathrm{NaCl}$. By using $2.0 \mathrm{ml}$. undiluted $\mathrm{HCl}$ no retention losses due to chloride were found. For polarography the $\mathrm{HCl}$ is diluted to about normal. Minor variations in normality are of no consequence because the unknown lead is compared against a standard lead addition under the same conditions in the polarograph cell. Porcelain crucibles were not found to be satisfactory, due to serious etching when the ash was dissolved in $\mathrm{HCl}$ and stirred with a glass rod.

I should like to thank Dr. S. G. Rainsford for advice and encouragement, and Dr. R. Owen, H.M. Medical Inspector of Factories, for the photographs.

\section{REFERENCES}

Analytical Methods Committee (1959). Analyst, 84, 127.

Fairhall, L. T. (1922). F. industr. Hyg., 4, 9.

Ferrett, D. J. Milner, G. W. C., and Smales, A. A. (1954). Analyst, 79, 73 I.

Gorsuch, T. T. (1959). Ibid., 84, 135.

Hamilton, E. I., Minski, M. J., and Cleary, J. J. (1967). Ibid., 92, 257.

Piper, C. S. (1944). Soil and Plant Analysis. Interscience Publishers, New York.

Tyler, J. F. C. (1964). Analyst, 89, 775. 